Фармацевтична технологія, біофармація, гомеопатія

Pharmaceutical technology, biopharmacy, homeopathy

УДК 615.31:547.792]-021.633:615.453.6.012-046.67

DOI https://doi.org/10.11603/2312-0967.2019.1.9882

\title{
ПІДБІР ДОПОМІЖНИХ РЕЧОВИН 3 МЕТОЮ СТВОРЕННЯ ТАБЛЕТОК МЕТИЛАМОНІЮ 2-[(4-АМІНО-5-ФЕНІЛ-4Н-1,2,4-ТРІАЗОЛ-3-ІЛ)ТІО]АЦЕТАТУ МЕТОДОМ ВОЛОГОї ГРАНУЛЯЦІї
}

\author{
Є. С. Пругло, О. С. Бідненко \\ Запорізький державний медичний університет
bidnenko2012@gmail.com
}

Мета роботи. Вивчення впливу допоміжних речовин на фрармако-технологічні властивості таблеток метиламонію 2-[(4-аміно-5-среніл-4Н-1,2,4-тріазол-3-іл)тіо]ацетату, підбір їх кращих поєднань.

Матеріали і методи. Використовували обладнання для отримання таблеток і визначення фрармако-технологічних характеристик: однорідність маси, стираність, розпадання, стійкість таблеток до роздавлювання. Досліджували вплив 16 допоміжних речовин на вказані фрармако-технологічні показники таблеток.

Результати й обговорення. Для отримання таблеток використано метод вологої грануляції. В процесі підбору попереднього складу допоміжних речовин використано один із планів дисперсійного аналізу - чотирифакторний експеримент на основі греко-латинського квадрата. Допоміжні речовини розподілено на чотири групи: наповнювачі, розпушувачі, зв'язуючі, ковзні і змащуючі. Досліджено вплив чотирьох груп допоміжних речовин на фрармакотехнологічні характеристики таблеток метиламонію 2-[(4-аміно-5-среніл-4Н-1,2,4-тріазол-3-іл)тіо]ацетату.

Висновки. Підібрано допоміжні речовини для подальших досліджень щодо отримання таблеток метиламонію 2-[(4-аміно-5-среніл-4Н-1,2,4-тріазол-3-іл)тіо]ацетату методом вологої грануляції: цукрова пудра (наповнювач), натрій кроскармелоза (розпушувач), 4 \% розчин ПВП 17К (зв'язуюча речовина), натрій лаурилсульфат (ковзна і змащуюча речовина).

Ключові слова: 1,2,4-тріазол; таблетки; допоміжні речовини; волога грануляція.

Вступ. Ключові клінічні ознаки хронічної серцевої недостатності (XCH) значною мірою визначаються затримкою натрію і води в організмі. Задишка, периферичні і порожнинні набряки, збільшення печінки, ціаноз, збільшення маси тіла, хрипи в легенях - це ознаки, що виникають у результаті застою. Саме це спричиняє суттєве погіршення якості життя (ЯЖ) хворих. Накопичення рідини відбувається за рахунок активації ренін-ангіотензин-альдостеронової системи, симпатоадреналової системи, ендотеліну і вазопресину; виведенню рідини сприяють інші гормони - натрій уретичний пептид, брадикінін і простациклін. Діуретичні препарати, основною метою застосування яких є збільшення виведення нирками натрію і води, усувають задишку і набряки, тим самим істотно поліпшують ЯЖ пацієнтів із ХCH.

Сполука метиламонію 2-[(4-аміно-5-среніл-4H1,2,4-тріазол-3-іл)тіо]ацетат вперше синтезована на кафедрі токсикологічної та неорганічної хімії Запорізького державного медичного університету [1]. Згідно з фрармакологічними дослідженнями вона проявляє діуретичні властивості. При вивченні фрармакокінетичних властивостей синтезованої субстанції per os на щурах встановлено, що час досягнення максимальної концентрації у плазмі крові становить 0,25 год, а показник напіввиведення - 2,21 год [1].
Відомо, що терапевтична активність лікарської речовини досягається тільки за умови призначення її в раціональній лікарській фрормі. Це допомагає також уникнути багатьох побічних ефектів лікарських препаратів на організм. Таким чином, можна припустити, що кращою лікарською фрормою для застосування даної субстанції будуть таблетки.

Отже, актуальною $є$ розробка технології таблеток метиламонію 2-[(4-аміно-5-среніл-4Н-1,2,4-тріазол-3іл)тіо]ацетату. Під час фрармакологічних досліджень було підібрано оптимальну дозу препарату на одне приймання, що становила 150 мг.

Мета роботи - вивчення впливу різних груп допоміжних речовин на фрармако-технологічні властивості таблеток метиламонію 2-[(4-аміно-5-френіл-4Н-1,2,4тріазол-3-іл)тіо]ацетату.

Матеріали і методи. Для прогнозування та оптимізації технологічних процесів застосовується математичне планування експерименту, що увійшло в технологічну науку та практику. Його використання сприяє зменшенню похибки експерименту, кількості експериментальних досліджень, встановленню взаємодії між фракторами тощо [2, 3].

До всіх таблеток, які розробляються в лабораторних умовах, а в подальшому їхня технологія масштабується в промислове виробництво, висуваються вимоги,

ISSN 2312-0967. Фармацевтичний часопис. 2019. № 1 
регламентовані діючою Фармакопеєю України - фрармако-технологічні показники, які введені у ДФУ [4].

У дослідженнях використано таблетопрес (Білорусь) та обладнання для визначення однорідності маси таблеток (Mettler Toledo A B54-S, Швейцарія), стираності (Pharma test D-63512 Hainburg, Німеччина), стійкості до роздавлювання (Pharma test РTB 311E Hainburg, Німеччина), часу розпадання (ERWEKA D-63150, Німеччина).

У ході роботи досліджували 16 допоміжних речовин, які володіють різними фрізичними та технологічними властивостями [5-7]. Допоміжні речовини були розділені на 4 групи - залежно від їхнього призначення і фрункції у таблетках (табл. 1).

Враховуючи дані літератури та досвід попередніх технологічних досліджень, запропоновано наступний теоретичний склад таблеток (табл. 2).

Результати й обговорення. При вивченні чотирьох якісних фракторів використовували один із планів дисперсійного аналізу - чотирифракторний експеримент на основі греко-латинського квадрата [3].

Матриця планування експерименту та результати дослідження наведено в таблиці 3. Для достовірності (для виключення помилки) результатів дослідження кожного параметра проводили дві серії дослідів.

Результати експериментальних досліджень піддавали дисперсійному аналізу, на основі якого робили
Фармацевтична технологія, біофармація, гомеопатія Pharmaceutical technology, biopharmacy, homeopathy

висновок про вплив вивчених фракторів на фрармакотехнологічні властивості таблеток метиламонію 2-[(4-аміно-5-среніл-4Н-1,2,4-тріазол-3-іл)тіо]ацетату: однорідність маси таблеток, розпадання, стираність та стійкість таблеток до роздавлювання.

Результати дисперсійного аналізу показали, що на однорідність маси таблеток впливають всі чотири вивчені фрактори: D > C > B > A.

Результати дослідження впливу ковзних і змащуючих речовин на однорідність маси таблеток представлені на рисунку 1.

Найкращі показники однорідності маси спостерігали при використанні ковзних речовин натрій лаурилсульрату ( $\pm 2,14 \%)$ та МКЦ 200 ( $\pm 2,48 \%)$, які мають деяку перевагу над просолвом 90 ( $\pm 2,74 \%)$ та значну над тальком ( $\pm 4,54 \%)$.

Аналіз впливу зв'язуючих речовин на однорідність маси таблеток показав, що найкращі показники спостерігали при використанні крохмального клейстеру $( \pm 1,71 \%)$ і розчину ПВП 17К ( $\pm 2,10 \%)$, які мають перевагу над розчинами МЦ 15 ( $\pm 3,62 \%)$ і ГПМЦ $( \pm 4,46 \%)$.

Серед розпушувачів кращі показники однорідності маси таблеток спостерігали при використанні натрій кроскармелози ( $\pm 2,31 \%)$, який має перевагу над полівінілпіролідоном (3,06 \%), крохмалем картопляним $( \pm 3,68 \%)$ та крохмалем кукурудзяним ( $\pm 3,85 \%)$.

Таблиця 1. Допоміжні речовини, які вивчали при розробці складу таблеток

\begin{tabular}{|c|c|}
\hline Фактори & Рівні фракторів \\
\hline $\begin{array}{l}\text { A - Наповнювачі на основі цукрів і } \\
\text { мікрокристалічної целюлози }\end{array}$ & $\begin{array}{l}\mathrm{a}_{1}-\text { цукрова пудра } \\
\mathrm{a}_{2}-\text { лактоза моногідрат } \\
\mathrm{a}_{3}-\text { МКЦ } 102 \\
\mathrm{a}_{4}-\text { сорбіт } \\
\end{array}$ \\
\hline В - Розпушувачі & $\begin{array}{l}\mathrm{b}_{1}-\text { крохмаль кукурудзяний } \\
\mathrm{b}_{2}-\text { крохмаль картопляний } \\
\mathrm{b}_{3}-\text { полівінілпіролідон } \\
\mathrm{b}_{4}-\text { натрій кроскармелоза }\end{array}$ \\
\hline C - Зв'язуючі & $\begin{array}{l}\mathrm{c}_{1}-3 \text { \% крохмальний клейстер } \\
\mathrm{c}_{2}-2,5 \% \text { р-н МЦ } 15 \\
\mathrm{c}_{3}-3 \% \text { р-н ГПМЦ } \\
\mathrm{c}_{4}-4 \% \text { р-н ПВП } 17 \mathrm{~K}\end{array}$ \\
\hline D - Ковзні і змащуючі & $\begin{array}{l}\mathrm{d}_{1}-\text { тальк } \\
\mathrm{d}_{2}-\text { просолв } 90 \\
\mathrm{~d}_{3}-\text { натрій лаурилсульсрат } \\
\mathrm{d}_{4}-\text { МКЦ } 200\end{array}$ \\
\hline
\end{tabular}

Таблиця 2. Теоретичний склад на одну таблетку

\begin{tabular}{|l|c|}
\hline Діюча речовина & $0,1500(60 \%)$ \\
\hline Наповнювачі (фактор А) & $0,0625(25 \%)$ \\
\hline Розпушувачі (фрактор B) & $0,0275(11 \%)$ \\
\hline Зв'язуючі (фрактор С) & Q.s. \\
\hline Ковзні і змащуючі (фактор D) & $0,0075(3 \%)$ \\
\hline Кальцій стеарат & $0,0025(1 \%)$ \\
\hline
\end{tabular}

ISSN 2312-0967. Pharmaceutical review. 2019. № 1 
Фармацевтична технологія, біофармація, гомеопатія Pharmaceutical technology, biopharmacy, homeopathy

Таблиця 3. Матриця планування експерименту та результати дослідження таблеток

\begin{tabular}{|c|c|c|c|c|c|c|c|c|c|c|c|c|}
\hline $\begin{array}{c}\text { № } \\
\text { 3/n }\end{array}$ & $\mathrm{A}$ & $\mathrm{B}$ & $\mathrm{C}$ & $\mathrm{D}$ & $\mathrm{y}_{1}$ & $\mathrm{y}_{1}^{\prime}$ & $\mathrm{y}_{2}$ & $\mathrm{y}_{2}^{\prime}$ & $\mathrm{y}_{3}$ & $\mathrm{y}_{3}^{\prime}$ & $\mathrm{y}_{4}$ & $\mathrm{y}_{4}{ }$ \\
\hline 1 & $\mathrm{a}_{1}$ & $\mathrm{~b}_{1}$ & $\mathrm{c}_{1}$ & $\mathrm{~d}_{1}$ & 4,08 & 4,27 & 21,17 & 22,45 & 1,08 & 1,21 & 42,7 & 42,3 \\
\hline 2 & $\mathrm{a}_{1}$ & $\mathrm{~b}_{2}$ & $\mathrm{c}_{2}$ & $\mathrm{~d}_{4}$ & 3,60 & 3,01 & 17,21 & 18,07 & 0,57 & 0,62 & 37,8 & 34,5 \\
\hline 3 & $\mathrm{a}_{1}$ & $\mathrm{~b}_{3}$ & $\mathrm{c}_{3}$ & $\mathrm{~d}_{2}$ & 3,12 & 3,19 & 13,21 & 13,43 & 0,77 & 0,72 & 58,4 & 88,1 \\
\hline 4 & $\mathrm{a}_{1}$ & $\mathrm{~b}_{4}$ & $\mathrm{c}_{4}$ & $\mathrm{~d}_{3}$ & 0,72 & 0,64 & 11,40 & 11,23 & 0,46 & 0,51 & 47,7 & 48,2 \\
\hline 5 & $\mathrm{a}_{2}$ & $\mathrm{~b}_{1}$ & $\mathrm{c}_{2}$ & $\mathrm{~d}_{3}$ & 3,64 & 3,51 & 19,35 & 19,02 & 0,59 & 0,63 & 62,2 & 62,5 \\
\hline 6 & $\mathrm{a}_{2}$ & $\mathrm{~b}_{2}$ & $\mathrm{c}_{1}$ & $\mathrm{~d}_{2}$ & 0,92 & 1,09 & 11,21 & 11,08 & 0,65 & 0,60 & 67,5 & 67,1 \\
\hline 7 & $\mathrm{a}_{2}$ & $\mathrm{~b}_{3}$ & $\mathrm{c}_{4}$ & $\mathrm{~d}_{4}$ & 1,32 & 1,57 & 18,24 & 18,02 & 1,30 & 1,14 & 38,8 & 38,2 \\
\hline 8 & $\mathrm{a}_{2}$ & $\mathrm{~b}_{4}$ & $\mathrm{c}_{3}$ & $\mathrm{~d}_{1}$ & 3,48 & 3,61 & 10,43 & 10,21 & 0,51 & 0,66 & 22,8 & 23,3 \\
\hline 9 & $\mathrm{a}_{3}$ & $\mathrm{~b}_{1}$ & $\mathrm{c}_{3}$ & $\mathrm{~d}_{4}$ & 4,56 & 4,12 & 17,42 & 17,09 & 0,70 & 0,75 & 57,3 & 56,6 \\
\hline 10 & $\mathrm{a}_{3}$ & $\mathrm{~b}_{2}$ & $\mathrm{c}_{4}$ & $\mathrm{~d}_{1}$ & 3,60 & 3,72 & 15,26 & 16,14 & 0,89 & 0,84 & 54,6 & 55,5 \\
\hline 11 & $\mathrm{a}_{3}$ & $\mathrm{~b}_{3}$ & $\mathrm{c}_{1}$ & $\mathrm{~d}_{3}$ & 0,76 & 0,93 & 14,34 & 14,08 & 0,96 & 1,03 & 41,12 & 41,1 \\
\hline 12 & $\mathrm{a}_{3}$ & $\mathrm{~b}_{4}$ & $\mathrm{c}_{2}$ & $\mathrm{~d}_{2}$ & 4,08 & 4,26 & 18,01 & 18,24 & 0,50 & 0,56 & 38,1 & 37,4 \\
\hline 13 & $\mathrm{a}_{4}$ & $\mathrm{~b}_{1}$ & $\mathrm{c}_{4}$ & $\mathrm{~d}_{2}$ & 2,8 & 2,46 & 17,16 & 17,37 & 0,85 & 0,81 & 39,3 & 39,9 \\
\hline 14 & $\mathrm{a}_{4}$ & $\mathrm{~b}_{2}$ & $\mathrm{c}_{3}$ & $\mathrm{~d}_{3}$ & 3,36 & 3,54 & 19,08 & 18,44 & 0,73 & 0,77 & 31,5 & 31,4 \\
\hline 15 & $\mathrm{a}_{4}$ & $\mathrm{~b}_{3}$ & $\mathrm{c}_{2}$ & $\mathrm{~d}_{1}$ & 7,0 & 6,56 & 11,20 & 11,39 & 0,59 & 0,55 & 41,6 & 41,8 \\
\hline 16 & $\mathrm{a}_{4}$ & $\mathrm{~b}_{4}$ & $\mathrm{c}_{1}$ & $\mathrm{~d}_{4}$ & 0,64 & 1,02 & 13,14 & 13,54 & 0,86 & 0,89 & 51,7 & 51,5 \\
\hline
\end{tabular}

$\mathrm{y}_{1}$ і $\mathrm{y}_{1}^{\prime}$ - однорідність маси таблеток першої і другої серії, \%;

$\mathrm{y}_{2}$ i $\mathrm{y}_{2}^{\prime}$ - розпадання таблеток першої і другої серії, хв;

$\mathrm{y}_{3}$ і $\mathrm{y}_{3}^{\prime}$ - стираність таблеток першої і другої серії, \%;

$\mathrm{y}_{4}$ iу⿰亻 $_{4}^{\prime}$ - стійкість таблеток першої і другої серії до роздавлювання, $\mathrm{H}$.

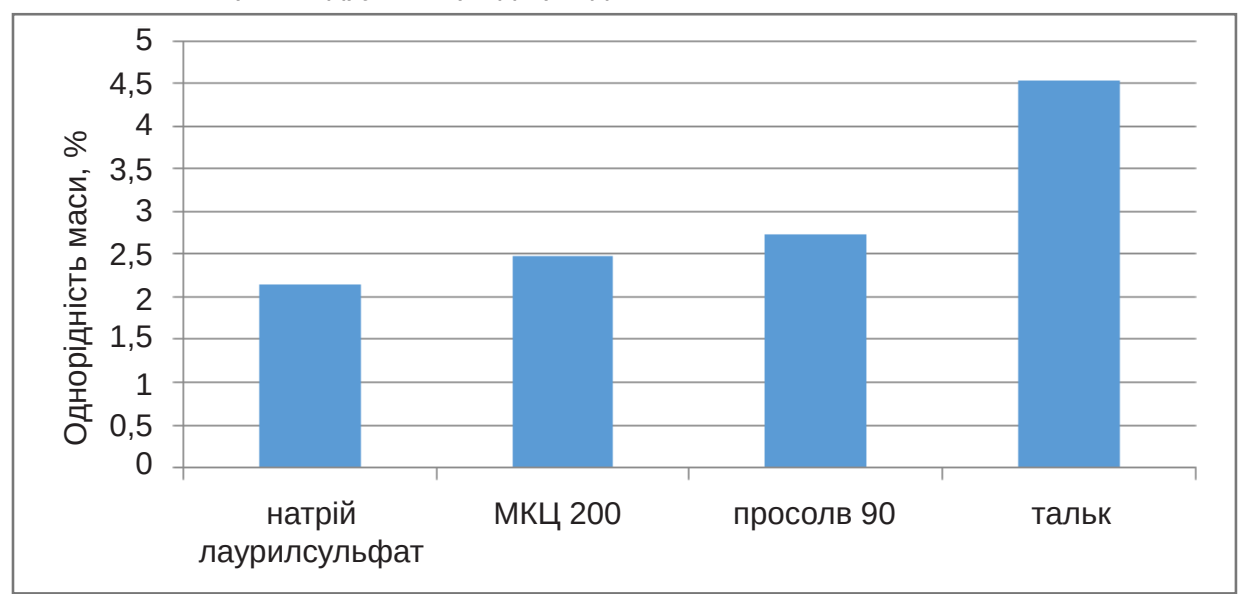

Рис. 1. Вплив ковзних і змащуючих речовин (фрактор D) на однорідність маси таблеток.

Серед наповнювачів на основі цукрів та мікрокристалічної целюлози на однорідність маси таблеток найкращі показники спостерігали при використанні цукрової пудри ( $\pm 2,39 \%)$ і лактози моногідрату $( \pm 2,82 \%)$, які мають перевагу над сорбітом $( \pm 3,25 \%)$ та МКЦ 102 ( $\pm 3,42 \%)$.

На розпадання таблеток впливають всі чотири вивчені фрактори, які за значущістю впливу розташовуються у ряді: $\mathrm{B}>\mathrm{D}>\mathrm{A}>\mathrm{C}$.

Вплив природи розпушувачів на розпадання таблеток зображено на рисунку 2.

Найшвидше розпадалися таблетки, отримані з використанням натрій кроскармелози $( \pm 13,27)$, як роз- пушувача, який виявився кращим від полівінілпіролідону $( \pm 14,24)$, крохмалю кукурудзяного $( \pm 15,81)$ та крохмалю картопляного $( \pm 18,88)$.

Найменший час розпадання мали таблетки, до складу яких в якості ковзної речовини входив тальк $( \pm 14,78)$, трохи гірші результати мали просолв 90 $( \pm 14,96)$, натрію лаурилсульфрат $( \pm 15,86)$ та МКЦ 200 $( \pm 16,59)$

Аналіз впливу наповнювачів на основі цукрів та МКЦ на розпадання таблеток показав, що при використанні лактози моногідрату таблетки розпадалися найшвидше $( \pm 14,69)$, ніж при використанні сорбіту $( \pm 15,16)$, цукрової пудри $( \pm 16,02)$ та МКЦ $102( \pm 15,16)$.

ISSN 2312-0967. Фармацевтичний часопис. 2019. № 1 
Фармацевтична технологія, біофармація, гомеопатія Pharmaceutical technology, biopharmacy, homeopathy

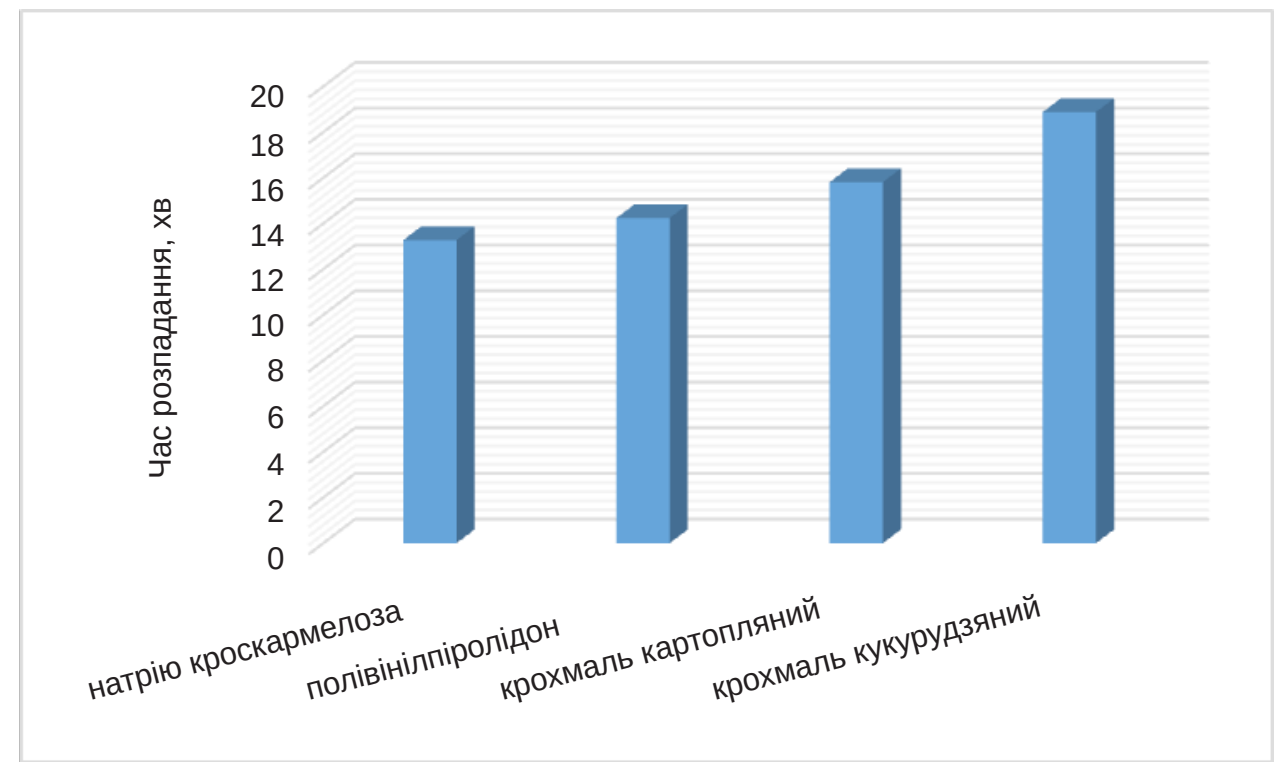

Рис. 2. Вплив розпушувачів (фрактор В) на розпадання таблеток.

При використанні зв'язуючого розчину ГПМЦ $( \pm 14,91)$ таблетки розпадались швидше, оскільки і при застосуванні крохмального клейстеру $( \pm 15,13)$. Обидва застосовані розчини зв'язуючих речовин мали незначну перевагу над розчинами МЦ 15 $( \pm 15,60)$ та ПВП 17К $( \pm 16,56)$.

Результати дисперсійного аналізу дозволили встановити, що на стираність таблеток впливають всі вивчені фрактори, а сила впливу відображена рядом $\mathrm{C}>\mathrm{B}>\mathrm{D}>\mathrm{A}$.

Результати вивчення впливу природи зв'язуючої речовини на стираність таблеток представлено на рисунку 3.

Дані рисунка 3 показують, що найменшу стираність мають таблетки, отримані при використанні роз- чинів МЦ $15( \pm 0,57)$ та ГПМЦ $( \pm 0,7)$. Вони мають незначну перевагу над ПВП $17 \mathrm{~K}( \pm 0,85)$ та крохмальним клейстером $( \pm 0,91)$.

Найменшу стираність мають таблетки, отримані при використанні натрій кроскармелози $( \pm 0,61)$, як розпушувача, яка має значну перевагу над крохмалем картопляним $( \pm 0,71)$, крохмалем кукурудзяним $( \pm 0,82)$ та полівінілпіролідоном $( \pm 0,88)$.

Вплив ковзних речовин позначається найменшою стираністю таблеток, отриманих 3 використанням просолву 90 ( $\pm 0,68)$, який має незначну перевагу над тальком $( \pm 0,71)$, натрій лаурилсульфатом $( \pm 0,79)$ та МКЦ $200( \pm 0,85)$.

Аналіз впливу наповнювачів на основі цукрів та МКЦ (фрактор А) на стираність таблеток показав, що

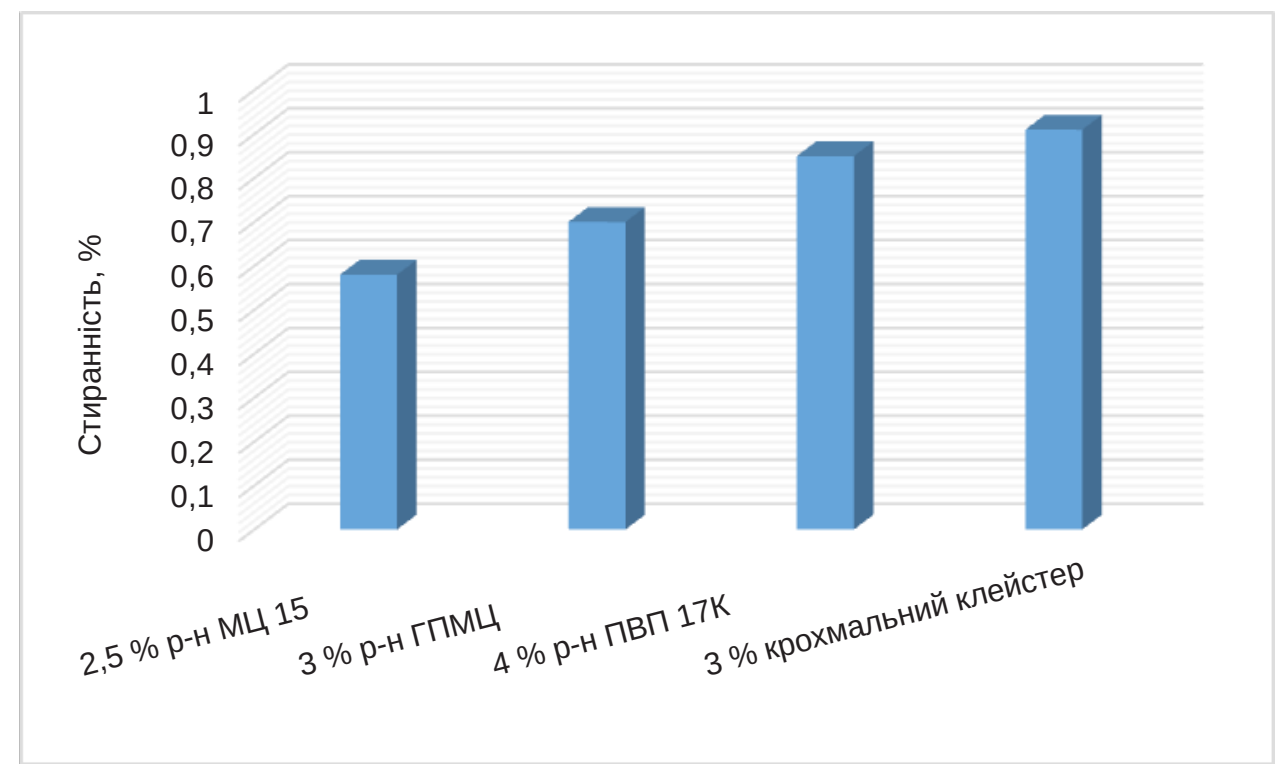

Рис. 3. Вплив зв'язуючих речовин (фактор С) на стираність таблеток.

ISSN 2312-0967. Pharmaceutical review. 2019. № 1 
Фармацевтична технологія, біофармація, гомеопатія Pharmaceutical technology, biopharmacy, homeopathy

найменшу стираність мають таблетки, отримані при використанні цукрової пудри $( \pm 0,74)$, що має незначну перевагу над лактози моногідратом $( \pm 0,75)$, МКЦ $102( \pm 0,76)$ та сорбітом $( \pm 0,78)$.

Результати дисперсійного аналізу показали, що на стійкість таблеток до роздавлювання вивчені фрактори впливають в ряді: $\mathrm{D}>\mathrm{B}>\mathrm{A}>\mathrm{C}$.

Результати вивчення впливу природи ковзних і змащуючих речовин на стійкість отримуваних таблеток до роздавлювання представлено на рисунку 4.

Аналіз даних рисунка 4 показав, що силу впливу ковзних речовин на стійкість таблеток до роздавлювання можна відобразити наступною послідовністю: просолв $90( \pm 40,57)>$ МКЦ $200( \pm 45,7)>$ натрію лаурилсульфрат $(45,8)>$ тальк $( \pm 54,47)$.

Силу впливу розпушувачів на стійкість таблеток до роздавлювання можна зобразити наступною послідовністю: крохмаль кукурудзяний $( \pm 40,09)>$ полівінілпіролідон $( \pm 47,49)>$ крохмаль картопляний $(48,64)$ > натрій кроскармелоза $(50,35)$.
Найстійкіші до роздавлювання таблетки отримали при використанні цукрової пудри $( \pm 41,09)$, яка має незначну перевагу над лактозою моногідратом $( \pm 47,71)$, МКЦ $102(47,8)$ та сорбітом $( \pm 49,96)$.

Аналіз впливу зв'язуючих речовин на стійкість таблеток до роздавлювання показує, що найміцніші таблетки було отримано при використанні 3 \% крохмального клейстеру $( \pm 44,49)$, який має перевагу над $3 \%$ розчином ГПМЦ $( \pm 45,27), 4 \%$ розчином ПВП $17 \mathrm{~K}$ $( \pm 46,17), 2,5 \%$ розчином МЦ $15( \pm 50,63)$.

Отримані результати дали змогу визначити найкраще поєднання рівнів вивчених фракторів для подальших досліджень. Співвідношення допоміжних речовин у серії № 4 (табл. 3) було запропоновано як попередній склад таблеток метиламонію 2-[(4-аміно5-среніл-4Н-1,2,4-тріазол-3-іл)тіо]ацетату: а 1 (цукрова пудра), b (натрій кроскармелоза), с $17 \mathrm{~K}$ ) і $\mathrm{d}_{3}$ (натрій лаурилсульфрат). У ході дослідження встановлено, що всі таблетки з даним складом допоміжних речовин відповідали вимогам вивчених фрармако-технологічних показників, які рекоментує ДФУ.

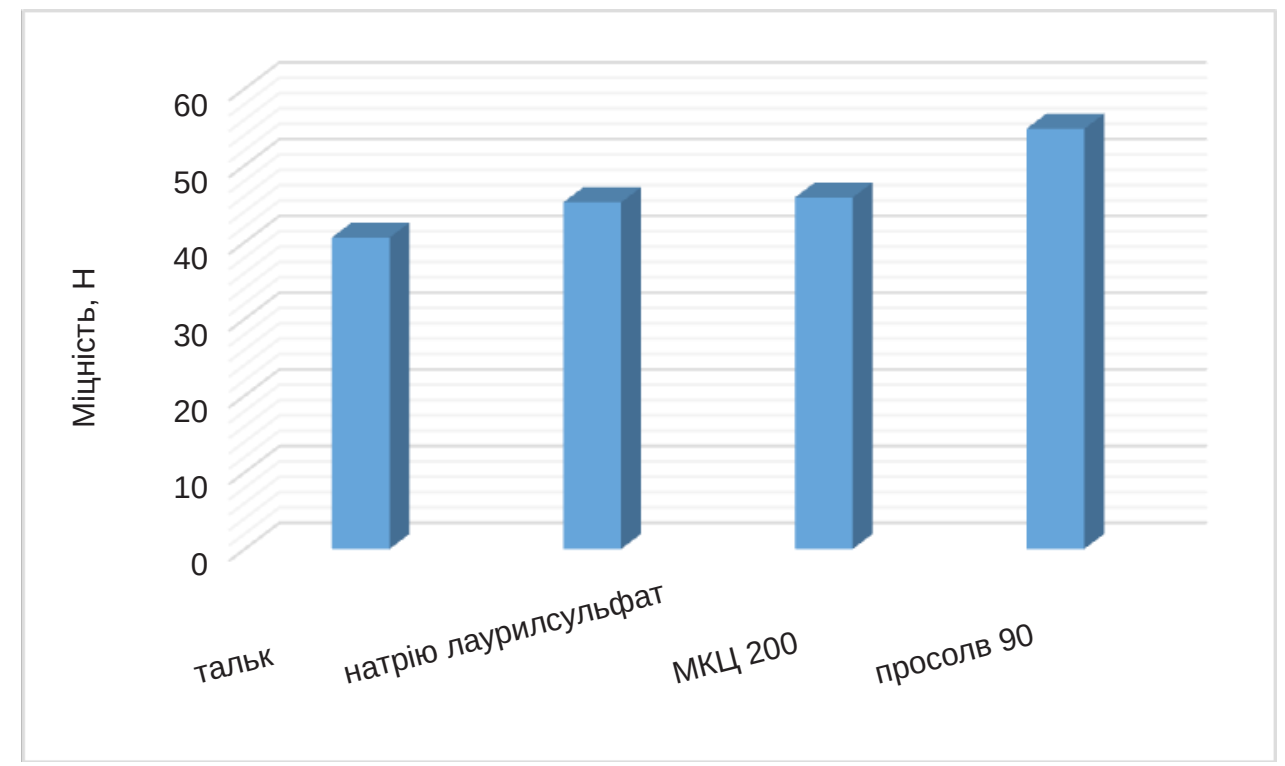

Рис. 4. Вплив ковзних і змащуючих речовин (фактор D) на стійкість таблеток до роздавлювання.

Висновки. 1. Досліджено вплив чотирьох груп допоміжних речовин на фрармако-технологічні характеристики таблеток метиламонію 2-[(4-аміно-5френіл-4Н-1,2,4-тріазол-3-іл)тіо]ацетату та підтверджено можливість їх отримання методом вологої грануляції.

2. Найкращі фрармако-технологічні показники мали таблетки, отримані 3 такими допоміжними речовинами: цукрова пудра, натрій кроскармелоза, натрій лаурилсульфат і 4 \% розчин ПВП $17 \mathrm{~K}$. Цей склад було обрано для подальших досліджень.

Конфлікт інтересів: відсутній.

Conflicts of interest: author has no conflict of interest to declare. 


\title{
ПОДБОР ВСПОМОГАТЕЛЬНЫХ ВЕЩЕСТВ С ЦЕЛЬЮ СОЗДАНИЯ ТАБЛЕТОК МЕТИЛАМОНИЯ 2-[(4-АМИНО-5-ФЕНИЛ-4Н-1,2,4-ТРИАЗОЛ-3-ИЛ)ТИО]АЦЕТАТА МЕТОДОМ ВЛАЖНОЙ ГРАНУЛЯЦИИ
}

\author{
Е. С. Пругло, А. С. Бидненко \\ Запорожский государственный медицинский университет \\ bidnenko2012@gmail.com
}

\begin{abstract}
Цель работы. Изучение влияния вспомогательных веществ на фрармако-технологические свойства таблеток метиламония 2-[(4-амино-5-сренил-4Н-1,2,4-триазол-3-ил) тио]ацетата, подбор их лучших сочетаний.

Материалы и методы. Использовали оборудование для получения таблеток и определения фрармакотехнологических характеристик: однородность массы, прочность таблеток на истирание, распадаемость, устойчивость таблеток к раздавливанию. Исследовали влияние 16 вспомогательных веществ на фрармакотехнологические показатели таблеток.

Результаты и обсуждение. Для получения таблеток использован метод влажной грануляции. В процессе подбора предварительного состава вспомогательных веществ использован один из планов дисперсионного анализа четырехфакторный эксперимент на основе греко-латинского квадрата. Вспомогательные вещества разделены на четыре группы: наполнители, разрыхлители, связующие, скользящие и смазывающие. Исследовано влияние четырех групп вспомогательных веществ на фармако-технологические характеристики таблеток метиламония 2-[(4-амино-5-сренил-4Н-1,2,4-триазол-3-ил) тио]ацетата.

Выводы. Подобраны вспомогательные вещества для последующего получения таблеток метиламония 2-[(4-амино5-сренил-4Н-1,2,4-триазол-3-ил) тио]ацетата методом влажной грануляции: сахарная пудра (наполнитель), натрий кроскармеллоза (разрыхлитель), 4 \% раствор ПВП 17К (связующее вещество), натрий лаурилсульфат (скользящее и смазывающее вещество).
\end{abstract}

Ключевые слова: 1,2,4-триазол; таблетки; вспомогательные вещества; влажная грануляция.

\section{SELECTION OF EXCIPIENTS FOR TABLETS CREATION WITH METHYLAMMONIUM 2-[(4-AMINO-5- PHENYL-4H-1,2,4-TRIAZOL-3-YL)THIO] TABLETS ACETATE USING WET GRANULATION}

\author{
Ye. S. Pruglo, O. S. Bidnenko \\ Zaporizhzhia State Medical University \\ bidnenko2012@gmail.com
}

The aim of the work. Studying of the excipients influence on the pharmaco-technological properties of methylammonium 2-[(4-amino-5-phenyl-4H-1,2,4-triazol-3-yl)thio]acetate tablets, selection of the best compositions of them.

Materials and Methods. The equipment for getting tablets and determining of the pharmaco-technological characteristics: uniformity of mass, friability, disintegration of tablets, resistance to crushing of tablets was used. The influence of 16 excipients on the pharmaco-technological parameters of tablets was investigated.

Results and Discussion. The wet granulation method was used to obtain the tablets. In the process of selecting the previous composition of excipients, one of the dispersion analysis plans was used - a four-factor experiment based on the Graeco-Latin square. The excipients were divided into four groups: diluents, disintegrating agents, binders, glidants and lubricants. The influence of four groups of excipients on the pharmaco-technological characteristics of methylammonium 2-[(4-amino-5-phenyl-4H-1,2,4-triazol-3-yl)thio]acetate tablets was investigated.

Conclusions. The combination of excipients for the following research on development obtaining of methylammonium 2-[(4-amino-5-phenyl-4H-1,2,4-triazol-3-yl)thio]acetate tablets using wet granulation was found: sugar powder (diluent), sodium croscarmellose (disintegrating agent), 4 \% solution PVP 17K (binder), sodium laurylsulfate (glidant and lubricant).

Key words: 1,2,4- triazole; tablets; excipients; wet granulation.

\section{Список літератури}

1. Пат. на винахід № 114571 Україна, МПК: А61K 31/00, C07D 249/00. Похідні 5-среніл-4-аміно-1,2,4-триазол-3-тіонів, що проявляють діуретичну активність / Панасенко О. І., Книш Є. Г., Пругло Є. С. ; опубл. 26.06.2017, бюл. № 12/2017.
2. Оптимізація технологічних процесів створення лікарських засобів за допомогою математичного планування експерименту / Т. А. Грошовий, Н.М.Белей, Л. І. Кучеренко [та ін.] // Фармац. часоп. - 2007. - № 1. - С. 21-28.

ISSN 2312-0967. Pharmaceutical review. 2019. № 1 
Фармацевтична технологія, біофармація, гомеопатія Pharmaceutical technology, biopharmacy, homeopathy

3. Математичне планування експерименту при проведенні наукових досліджень в фрармації / [Грошовий Т. А., Марценюк В. П., Кучеренко Л. І. та ін.]. - Тернопіль : ТДМУ, 2008. - 368 с.

4. Державна Фармакопея України: в 3 т. / Державне підприємство «Український науковий фрармакопейний центр якості лікарських засобів». - 2-е вид. - Харків : Державне підприємство «Український науковий фрармакопейний центр якості лікарських засобів», 2015. - Т. 1. $-1128 \mathrm{c}$

5. Сучасний стан створення, виробництва та дослідження таблетованих лікарських препаратів. Повідо- млення 1. Фізичні та технологічні властивості лікарських і допоміжних речовин та їх вплив на вибір схеми виробництва таблеток / М. М. Васенда, Н.М.Белей, М. Б. Демчук [та ін.] // Фармац. часоп. -2009. - № 4. - C. $77-80$.

6. Handbook of Pharmaceutical Granulation Technology, 2nd edition / ed. by Parikh D. M. - Boca Raton, FL, USA: Taylor \& Francis Group, LLC, 2005. - P. 115-128.

7. Допоміжні речовини у виробництві ліків: навч. посіб. для студентів вищ. фрармац. навч. закл. / [О. А. Рубан, І. М. Перцев, С. А. Куценко та ін.]. - Харків : Золоті сторінки, 2016. - 720 с.

\section{References}

1. Panasenko OI, Knysh YH, Pruhlo YeS. Pat. № 114571 , Ukraine. Derivatives of 5-phenyl-4-amino-1,2,4-triazole3-thione exhibiting diuretic activity. opubl. 26.06.2017, Byul. № 12/2017; Ukrainian.

2. Hroshovyi TA, Belei NM, Kucherenko LI, Vasenda MM, Markiv NV, Tryhubchak OV, et al. [Optimization of technological processes of drugs creation by means of mathematical planning of experiment]. Farmatsevt chasop. 2007;1: 21-8. Ukrainian.

3. Hroshovyi TA, Martseniuk VP, Kucherenko LI, Vronska LV, Hurieieva SM. Mathematical planning of experiment in pharmacy. [Математичне планування експерименту при проведенні наукових досліджень в фрармації] Ternopil: Ternopil State Medical University; 2008. Ukrainian. 4. State Pharmacopoeia of Ukraine in 3 vol., 2nd edition. [Державна Фармакопея України: в 3 т.] Kharkiv: State

Enterprise "Ukrainian Scientific Pharmacopoeial Center for Quality of Medicines"; 2015.

5. Vasenda MM, Belei NM, Demchuk MB, Tryhubchak OV, Chubka MB, Hurieieva SM, et al. [The modern situation of the creation, manufacture and researches of tablet's medicines. Report 1]. Farmatsevt chasop. 2009;4: 77-80. Ukrainian.

6. Parikh DM (Ed.). Handbook of Pharmaceutical Granulation Technology, 2nd edition. Boca Raton, FL, USA: Taylor \& Francis Group, LLC; 2005.

7. Ruban OA, Pertsev IM, Kutsenko SA, Maslii YuS. Substances in the manufacture of drugs: teaching. manual for students of higher education [Допоміжні речовини у виробництві ліків: навч. посіб. для студентів вищ. фрармац. навч. закл.] Kharkiv: Zoloti storinky; 2016. Ukrainian

Надійшла до редакції / Received: 30.08.2018 Після доопрацювання / Revised: 03.10.2018, 15.01.2019 Прийнято до друку / Accepted: 22.02.2019

\section{Відомості про авторів:}

Пругло Є.С. - канд. фрармац. н., доц. кафр. клінічної фрармації, фрармакотерапії і управління та економіки фрармації, Запорізький державний медичний університет, Запоріжжя, Україна. E-mail: pruglo@bk.ru, ORCID 0000-0002-47057261

Бідненко О.С. - канд. фрармац. н., асистент кафедри фрармацевтичної хімії, Запорізький державний медичний університет, Запоріжжя, Україна. E-mail: bidnenko2012@gmail.com, ORCID 0000-0001-8020-9952

\section{Information about authors:}

Pruglo Ye.S. - PhD (Pharmaceutical Sciences), Assistant Professor, the Clinical Pharmacy, Pharmacotherapy, Management and Economics of Pharmacy Department, Zaporizhzhia State Medical University, Zaporizhzhia, Ukraine. E-mail: pruglo@bk.ru, ORCID 0000-0002-4705-7261

Bidnenko O.S. - PhD (Pharmaceutical Sciences), Assistant Professor, the Pharmaceutical Chemistry Department, Zaporizhzhia State Medical University, Zaporizhzhia, Ukraine. E-mail: bidnenko2012@gmail.com, ORCID 0000-00018020-9952 